\title{
Characterization of lorry washing sludge
}

Ana Isabel Moreno 1,*
Phone: + 34965903400
Email: anaisabel.moreno@ua.es

Rafael Font ${ }^{1}$

María Francisa Gómez-Rico ${ }^{1}$

Department of Chemical Engineering, University of Alicante, P.O. Box 99, 03080 Alicante, Spain

\section{Abstract}

The sludge generated by washing lorry refuse and some fractions of municipal solid waste have been studied, to justify that washing sludge presents no danger and can therefore be managed adequately in a landfill, as well as other municipal solid waste fractions. One problem attributed to this type of sludge is its high level of sulfide content, which causes this waste to be considered hazardous. The determination of sulfide content in the studied samples was carried out according to environmental protection agency methods $9030 \mathrm{~B}$ and 9034, and the results show that the sulfide concentration in the sludge is less than other fractions of the municipal solid waste treatment plants, which can properly composted, in which sulfides are oxidized to sulfates. Lorry washing sludge could therefore be managed in a municipal solid waste treatment plant.

\section{AQ1}

\section{Keywords}

Sludge

MSW (municipal solid waste)

Digestate

Compost 


\section{Introduction}

Wastewaters and sludges can cause some environmental problems, such as for instance, the generation of sulfide. Under anaerobic conditions, oxidized sulfur, mainly sulfate, is reduced to sulfide by the sulfate reducing bacteria $[1,2]$.

The sulfur cycle is linked to the carbon cycle in terms of mass transport, transformations and interfacial exchanges that occur in the solid phase, the water phase, and the gas phase [3]. In addition, there are biological desulfurization reactions of organic compounds containing sulfur, although this mechanism produces only small quantities of sulfide [4].

In an aqueous solution, sulfide $\left(\mathrm{S}^{2-}\right)$, hydrogen sulfide ions $\left(\mathrm{HS}^{-}\right)$, and hydrogen sulfide $\left(\mathrm{H}_{2} \mathrm{~S}\right)$ are forms of sulfides. The equilibrium is described in Eqs. 1 and 2. $\mathrm{S}^{2-}$ does not exist as a significant fraction, except at very high $\mathrm{pH}$. The concentration of $\mathrm{H}_{2} \mathrm{~S}$ and $\mathrm{HS}^{-}$is equal at $\mathrm{pH} 7$.

$$
\mathrm{H}_{2} \mathrm{~S} \leftrightarrow \mathrm{HS}^{-}+\mathrm{H}^{+} \quad\left(\mathrm{pk}_{1}=7\right)
$$

$$
\mathrm{HS}^{-}+\mathrm{OH}^{-} \leftrightarrow \mathrm{S}^{2-}+\mathrm{H}_{2} \mathrm{O} \quad\left(\mathrm{pk}_{2}=13.8\right)
$$

Only $\mathrm{H}_{2} \mathrm{~S}$ can be transferred to the air, so in alkaline conditions, the $\mathrm{HS}^{-}$ dominates and the emission of $\mathrm{H}_{2} \mathrm{~S}$ is reduced $[4,5]$. On the other hand, dissolved sulfide $\left(\mathrm{H}_{2} \mathrm{~S}, \mathrm{HS}^{-}\right.$, and $\left.\mathrm{S}^{2-}\right)$ can give rise to the formation of metal sulfides that precipitate and consequently the generated sludge contains sulfide.

Sewage sludges have been widely studied and their respective legislation provides the guidelines to manage them. As a matter of fact, the addition of some metals is widely used in the treatment of wastewaters to mitigate the $\mathrm{H}_{2} \mathrm{~S}$ production [2], mainly iron salts are employed [6-9]. The final disposals of the treated sludge in accordance with Spanish legislation can be: (1) its use for agriculture (RD 1310/1990), (2) incineration (RD 653/2003), (3) disposal to landfill (1481/2001). Nevertheless, no papers have been found studying the sludge generated from the washing of 
municipal solid waste (MSW) lorries, and moreover, the legislation does not consider its characterization and its management.

According to the property H12 of European Directives (Directive 2008/98/CEE), if a waste emits toxic or very toxic gases upon contact with air, with water, or with an acid, the waste is considered as a hazardous waste. Nevertheless, in the current European legislation, there is no numerical criterion for evaluating emissions of hydrogen sulfide or other toxic gases. The limit for hydrogen sulfide content was established at $500 \mathrm{mg} / \mathrm{kg}$ of waste by the US EPA, in chapter 7 of the SW-846 manual "Test Methods for Evaluating Solid Waste, Physical/Chemical Methods". These guideline values were valid in the USA until 1998, when they were removed, and so far no others have been proposed. The current revision of the SW-846 manual, published in 2004 makes no reference to these limits.

$\mathrm{H}_{2} \mathrm{~S}$ formation is a problem in the operation of wastewater treatment systems, because it is the main cause of odors and is also noted for its toxicity and its corrosive properties. Nevertheless, many solutions have been developed to control its emission, for instance: ensure alkaline conditions, addition of metal salts to precipitate sulfide, moderate oxygenation [9-11].

On the other hand, $\mathrm{H}_{2} \mathrm{~S}$ is commonly emitted from volcanoes, stagnant or polluted waters, hot springs, and underwater thermal vents [12]. These natural sources account for about $90 \%$ of the total hydrogen sulfide in the atmosphere. These thermal waters are the most studied and their beneficial biological effects are well known on the skin, the respiratory and vaginal mucous membrane and gastroenteric system $[13,14]$.

For the previous reasons, the property $\mathrm{H} 12$ of wastes in the European Directive 91/689/EEC generates a controversy, because in some cases, waste that has no kind of hazard is considered as hazardous waste.

The lorry washing sludge studied in this work is generated in an MSW treatment plant located in the Valencian Community. In this treatment plant, the lorries and the street cleaning machines are washed daily, and the wash-water with solids passes into a tank, in which the generated sludge settles and is removed every month. The medium of this wash-water is anaerobic and neutral-slightly alkaline; this fact promotes the formation of sulfides that precipitate in the lorry washing sludge. 
The MSW and the sewage sludge also generate $\mathrm{H}_{2} \mathrm{~S}$ and these materials are not considered as hazardous wastes. In addition, given that under aerobic conditions sulfides are oxidized to sulfates, the use of the lorry washing sludge for co-composting with other organic fractions could be a right solution [15].

The lorry washing sludge could also show other environmental problems, such as heavy metal content. The Council Decision of the European Union (2003/33/EC) also establishes criteria for the acceptance of waste at landfills. This Decision indicates limit values of some metals for nonhazardous waste and the testing consists in a leaching test.

Therefore, it is important to characterize the lorry washing sludge to deduce if it contains toxic substances and its correct treatment. It is also compared with other different fractions of the treatment plant to determinate if it can be properly managed in an MSW treatment plant.

\section{Materials and methods}

The sludge has been characterized and compared with other different fractions from the MSW treatment plant. The waste fractions studied were the following:

- Lorry washing sludge (three samples were collected in different seasons: autumn, winter, and summer).

- Fr. 4 MSW: Municipal solid waste with particle size less than $4 \mathrm{~cm}$ (this fraction is used for the anaerobic digestion and is the biomethanation input).

- Digestate: effluent of anaerobic digestion (biomethanation).

- Fresh compost: compost obtained after 21 days of composting formed from digestate and the intermediate particle size fraction of MSW (4$8 \mathrm{~cm})$.

- Stabilized compost: compost after more than 1 month of maturation; this fraction has a particle size less than $12 \mathrm{~mm}$.

- Rejected fraction: comprises the fraction of compost with a particle 
size greater than $12 \mathrm{~mm}$. This fraction is stabilized and deposited in a solid waste landfill and contains plastic, glass, and other nonfermentable materials.

These waste fractions were chosen because they are solid waste used to generate biogas and compost or to be refused in a landfill, and they are not considered as hazardous wastes. Therefore, if the chemical characterization of the lorry washing sludge results in a composition similar to these waste fractions studied, it can also be managed in the same way in the plant.

Samples were taken from the MSW treatment plant and from the tank with the washing sludge, trying to be representative of the corresponding wastes. The procedure for sampling is essential. Several numbers of samples were taken from different locations, and moreover, the physical size of the samples was maximized to increase sampling precision.

\section{Basic characterization}

Moisture content was determined by the weight loss at $105^{\circ} \mathrm{C}$ for $24 \mathrm{~h}$. The ash residue was obtained by calcinations at $850^{\circ} \mathrm{C}$; the quantity of volatiles was determined by the weight loss at $550{ }^{\circ} \mathrm{C}$ for $1 \mathrm{~h}$.

Dry samples were milled to carry out an elemental analysis of the major elements $(\mathrm{C}, \mathrm{H}, \mathrm{S}$, and $\mathrm{N})$ and the determination of metals. The elemental analysis was performed in a Perkin-Elmer 2400 apparatus and the determination of metals was carried out by an automatic sequential spectrometer X-ray Fluorescence model TW 1480 (semi-quantitative determination).

A Mitsubishi Chemical Corporation TOX-100 apparatus was used for halogen determination $(\mathrm{Cl}, \mathrm{Br}$, and $\mathrm{I})$. This equipment is equipped with a furnace where pyrolysis/combustions of samples were carried out. The gases from the thermal process were swept away to the dehydrating tube $\left(\mathrm{H}_{2} \mathrm{SO}_{4}\right.$ conc.), and afterward sent to a coulometric titration cell.

The determination of sulfide was carried out according to environmental protection agency (EPA) methods $9030 \mathrm{~B}$ and $9034[16,17]$ by distillation in an acid medium and a titrimetric determination of the sulfide. A modification of these methods was carried out, due to the high sulfide level that was expected in nearly samples. The samples ranged from 1 to $5 \mathrm{~g}$, 
which were less than the quantities indicated by Method 9030B. Dilutions of the gas scrubbing solution obtained in Method 9030B were done to use in the titrimetric determination (Method 9034), and the second gas scrubbing solution was analyzed individually to ensure a complete collection of the hydrogen sulfide gas released from the sample. Furthermore, the sulfide values were determined by duplicate analysis.

A Mettler Toledo thermobalance model TGA/SDTA851e/SF/1100 with TG-DTA was used to carry out the TG experiments. This apparatus has a horizontal furnace and a parallel-guided balance. The sample temperature was measured with a sensor placed just under the sample holder. For the pyrolysis runs, the atmosphere used was $\mathrm{He}$, and for the combustion runs, the atmosphere was $\mathrm{He}: \mathrm{O}_{2} 4: 1$. The heating rate was $10{ }^{\circ} \mathrm{C} \min ^{-1}$. The sample weights were around $5 \mathrm{mg}$.

The determination of semi-volatile organic compounds was carried out according to the EPA method 3545 [18]. This method uses elevated temperature $\left(100^{\circ} \mathrm{C}\right)$ and pressure $(1,500-2,000 \mathrm{psi})$ to extract water insoluble or slightly water soluble semi-volatile organic compounds, which may then be analyzed by the chromatographic procedure. Initially, the samples are spiked with $20 \mu \mathrm{L}$ of an internal deuterated standard solution which consisted of $2,000 \mu \mathrm{g} \mathrm{mL} \mathrm{m}^{-1}$ of each of the following compounds: 1,4-dichlorobenzene- $d_{4}$, naphthalene- $d_{8}$, acenaphthene- $d_{10}$, phenanthrene$d_{10}$, chrysene- $d_{12}$, and perylene- $d_{12}$. The extracts were concentrated in a rotary evaporator until nearly dry. One microliter of the concentrated solution was spiked with $10 \mu \mathrm{L}$ of anthracene- $d 10$ as recovery standards and injected into the chromatograph gas coupled to a mass spectrometer (Agilent GC-MS) with a HP-5 column. In accordance with the EPA 8270C method [19], a semi-quantitative estimation of the yields was calculated for any compound with the response factors of the standard with the nearest retention time. The recovery efficiency for the most volatile of the deuterated compounds (1,4-dichlorobenzene- $\left.d_{4}\right)$ presented a median value of $27 \%$. However, the recovery efficiencies for the rest of deuterated compounds ranged from 49 to $99 \%$ with a median value of $68 \%$.

In addition, dissolved oxygen, the redox potential, and $\mathrm{pH}$ were measured in the wash-water tank.

\section{Leachate test}


The leachates of the different samples were obtained according to the DIN 38414-S4 method [20] with a relation L/S of 1 liter/100 g dry solid, and an agitation around $70 \mathrm{rpm}$ by $25^{\circ} \mathrm{C}$ for $24 \mathrm{~h}$.

Table 1 shows the methods used to assess the parameters of the leachates from the different samples.

\section{Table 1}

Methods of leachate analysis

\begin{tabular}{|l|l|l|}
\hline Parameter & Analytical method & Experimental technique \\
\hline $\begin{array}{l}\text { Total } \\
\text { dissolved } \\
\text { solids (TDS) }\end{array}$ & $\begin{array}{l}\text { 2540C of Standard Methods of } \\
\text { Water and Wastewater 20th } \\
\text { Edition }\end{array}$ & \\
\hline $\begin{array}{l}\text { Dissolved } \\
\text { organic } \\
\text { carbon (DOC) }\end{array}$ & $\begin{array}{l}\text { 5310B of Standard Methods of } \\
\text { Water and Wastewater 20th } \\
\text { Edition }\end{array}$ & Shimadzu TOC-5000A \\
\hline $\begin{array}{l}\text { Chloride, } \\
\text { fluoride, and } \\
\text { sulfate }\end{array}$ & EPA 300.0A & $\begin{array}{l}\text { Ion Chromatograph DX5OO } \\
\text { DIONEX }\end{array}$ \\
\hline $\begin{array}{l}\text { Total } \\
\text { hydrocarbons }\end{array}$ & $\begin{array}{l}\text { 5520F of the Standard Methods } \\
\text { Edition and Wastewater 20th }\end{array}$ & $\begin{array}{l}\text { ICP (Inductively Coupled } \\
\text { Plasma) Perkin-Elmer } \\
\text { Optima 7300 }\end{array}$ \\
\hline Metals & EPA 6010B & $\begin{array}{l}\text { Perkin-Elmer Atomic } \\
\text { Absorption Spectrometer } \\
\text { 2100 }\end{array}$ \\
\hline Hg & EPA 7470A & \\
\hline & &
\end{tabular}

\section{Results and discussion}

In the tank, where the wash-water from the washing of the lorries was accumulated, the medium is anaerobic. Dissolved oxygen and the redox potential were measured in this water. The dissolved oxygen was less than $0.1 \mathrm{ppm}$ and the redox potential was a negative value, thus indicating that this is an anaerobic environment.

The $\mathrm{pH}$ was measured in the wash-water tank and results in a neutralslightly alkaline medium. The pHs of the lorry wash-water were 7.5, 7.9, 7.1 in autumn, winter and summer, respectively. According to the 
equilibrium of the sulfide, the formation of hydrogen sulfide $\left(\mathrm{H}_{2} \mathrm{~S}\right)$ decreases in alkaline conditions; therefore, there were low $\mathrm{H}_{2} \mathrm{~S}$ emissions and consequently there was no odor due to $\mathrm{H}_{2} \mathrm{~S}$ around the wash-water tank.

\section{Solid characterization}

Table 2 presents the elemental, volatiles, and moisture analysis of the different materials studied.

\section{Table 2}

Composition of the different materials

\begin{tabular}{|c|c|c|c|c|c|c|c|}
\hline \multirow{2}{*}{ 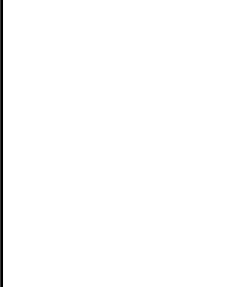 } & \multirow{2}{*}{$\begin{array}{l}\text { Moisture } \\
\text { (wt. \%) }\end{array}$} & \multicolumn{6}{|c|}{ Composition on dry basis (wt. \%). Mean value (range } \\
\hline & & $\begin{array}{l}\mathrm{C} \\
(\%)\end{array}$ & $\begin{array}{l}\mathbf{H} \\
(\%)\end{array}$ & $\begin{array}{l}\mathrm{N} \\
(\%)\end{array}$ & S (\%) & $\begin{array}{l}\text { Ash } \\
\text { content } \\
(\%)\end{array}$ & $\begin{array}{l}\mathrm{O}(\%) \mathrm{by} \\
\text { difference }\end{array}$ \\
\hline $\begin{array}{l}\text { Lorry } \\
\text { washing } \\
\text { sludge } \\
\text { (autumn) }\end{array}$ & $\begin{array}{l}57.2 \\
(64.4- \\
49.9)\end{array}$ & $\begin{array}{l}24.1 \\
(25.3- \\
23.3)\end{array}$ & $\begin{array}{l}2.5 \\
(2.6- \\
2.4)\end{array}$ & $\begin{array}{l}0.6 \\
(0.61- \\
0.55)\end{array}$ & $<0.1$ & $\begin{array}{l}58.7 \\
(64.0- \\
53.9)\end{array}$ & 14.1 \\
\hline $\begin{array}{l}\text { Lorry } \\
\text { washing } \\
\text { sludge } \\
\text { (winter) }\end{array}$ & $\begin{array}{l}67.4 \\
(75.7- \\
57.0)\end{array}$ & $\begin{array}{l}24.7 \\
(24.9- \\
24.5)\end{array}$ & $\begin{array}{l}2.5 \\
(2.6- \\
2.5)\end{array}$ & $\begin{array}{l}0.8 \\
(0.84- \\
0.79)\end{array}$ & $\begin{array}{l}0.10 \\
(0.13- \\
0.08)\end{array}$ & $\begin{array}{l}44.6 \\
(49.1- \\
38.6)\end{array}$ & 27.2 \\
\hline $\begin{array}{l}\text { Lorry } \\
\text { washing } \\
\text { sludge } \\
\text { (summer) }\end{array}$ & $\begin{array}{l}69.8 \\
(76.9- \\
60.1)\end{array}$ & $\begin{array}{l}22.6 \\
(24.1- \\
20.8)\end{array}$ & $\begin{array}{l}2.2 \\
(2.5- \\
2.0)\end{array}$ & $\begin{array}{l}0.7 \\
(0.8- \\
0.6)\end{array}$ & $<0.1$ & $\begin{array}{l}51.9 \\
(55.2- \\
46.3)\end{array}$ & 22.6 \\
\hline Digestate & $\begin{array}{l}65.7 \\
(70.2- \\
60.2)\end{array}$ & $\begin{array}{l}27.5 \\
(28.7- \\
26.2)\end{array}$ & $\begin{array}{l}4.2 \\
(4.5- \\
4.1)\end{array}$ & $\begin{array}{l}1.7 \\
(1.8- \\
1.6)\end{array}$ & $\begin{array}{l}0.3 \\
(0.3- \\
0.2)\end{array}$ & $\begin{array}{l}32.1 \\
(34.8- \\
28.1)\end{array}$ & 34.2 \\
\hline $\begin{array}{l}\text { Fr. } 4 \\
\text { MSW }\end{array}$ & $\begin{array}{l}57.6 \\
(66.2- \\
48.3)\end{array}$ & $\begin{array}{l}33.1 \\
(33.1- \\
33.0)\end{array}$ & $\begin{array}{l}4.30 \\
(4.30- \\
4.29)\end{array}$ & $\begin{array}{l}1.94 \\
(1.94- \\
1.93)\end{array}$ & $\begin{array}{l}0.13 \\
(0.14- \\
0.12)\end{array}$ & $\begin{array}{l}33.3 \\
(36.9- \\
28.0)\end{array}$ & 27.3 \\
\hline $\begin{array}{l}\text { Rejected } \\
\text { fraction }\end{array}$ & $\begin{array}{l}27.0 \\
(29.6- \\
24.4)\end{array}$ & $\begin{array}{l}38.5 \\
(38.6- \\
38.5)\end{array}$ & $\begin{array}{l}4.9 \\
(4.9- \\
4.8)\end{array}$ & $\begin{array}{l}1.7 \\
(1.8- \\
1.6)\end{array}$ & $\begin{array}{l}0.35 \\
(0.35- \\
0.35)\end{array}$ & $\begin{array}{l}17.5 \\
(19.8- \\
15.9)\end{array}$ & 37.1 \\
\hline $\begin{array}{l}\text { Fresh } \\
\text { compost }\end{array}$ & $\begin{array}{l}33.4 \\
(36.9- \\
29.6)\end{array}$ & $\begin{array}{l}36.7 \\
(36.9- \\
36.5)\end{array}$ & $\begin{array}{l}4.62 \\
(4.64- \\
4.61)\end{array}$ & $\begin{array}{l}1.89 \\
(1.90- \\
1.88)\end{array}$ & $\begin{array}{l}0.5 \\
(0.5- \\
0.4)\end{array}$ & $\begin{array}{l}25.4 \\
(27.5- \\
21.8)\end{array}$ & 30.9 \\
\hline $\begin{array}{l}\text { Stabilized } \\
\text { compost }\end{array}$ & $\begin{array}{l}14.9 \\
(17.3- \\
13.4)\end{array}$ & $\begin{array}{l}34.9 \\
(35.2- \\
34.7)\end{array}$ & $\begin{array}{l}4.1 \\
(4.2- \\
4.1)\end{array}$ & $\begin{array}{l}2.3 \\
(2.3- \\
2.2)\end{array}$ & $\begin{array}{l}0.5 \\
(0.6- \\
0.4)\end{array}$ & $\begin{array}{l}33.0 \\
(35.4- \\
31.7)\end{array}$ & 25.2 \\
\hline
\end{tabular}


It can be observed that the percentage of sulfur in the washing sludge is lower than in the rest of the samples analyzed. The sulfur in solids can be found as elemental sulfur, mineral sulfides, sulfates, and organic sulfur. Also, noteworthy is the higher ash content in the washing sludge samples.

The results of the determination of acid insoluble sulfide are shown in Table 3 . It can be observed that the lorry washing sludge has lower sulfide content than the digestate from the biomethanation. The occurrence of sulfide in an anaerobic environment causes several problems, such as odor nuisance, health effects, and the corrosion of the facilities due to hydrogen sulfide emissions. Chemical precipitation of dissolved sulfide by the addition of iron, as for instance $\mathrm{FeCl}_{2}$, is one of the most widely used methods to control $\mathrm{H}_{2} \mathrm{~S}$ emissions $[6,8,9,21,22]$. Besides iron, other metals also precipitate as metal sulfide [23]. The efficacy of the precipitation depends on some parameters: $\mathrm{pH}$, oxidation-reduction conditions, and metal concentrations [9]. In the anaerobic bioreactor from which the digestate is obtained, $\mathrm{FeCl}_{2}$ is added to precipitate the sulfide generated and to avoid the formation of $\mathrm{H}_{2} \mathrm{~S}$; therefore, it is obvious that the digestate has high or significant sulfide content. It is observed that summer sludge has the highest sulfide concentration, due to the fact that temperature benefits anaerobic decomposition.

\section{Table 3}

Results of acid insoluble sulfide, by method EPA 9030B. Mean value (range)

\begin{tabular}{|l|l|l|}
\hline & $\begin{array}{l}\text { Sulfides }(\mathbf{m g} / \mathbf{k g} \text { total } \\
\text { sample) }\end{array}$ & $\begin{array}{l}\text { Sulfides }(\mathbf{m g} / \mathbf{k g} \text { on dry } \\
\text { basis })\end{array}$ \\
\hline $\begin{array}{l}\text { Lorry washing sludge } \\
\text { autumn) }\end{array}$ & $160(172-154)$ & $403(433-386)$ \\
\hline $\begin{array}{l}\text { Lorry washing sludge } \\
\text { (winter) }\end{array}$ & $179(203-157)$ & $551(623-482)$ \\
\hline $\begin{array}{l}\text { Lorry washing sludge } \\
\text { (summer) }\end{array}$ & $483(507-451)$ & $1,601(1,681-1,493)$ \\
\hline Digestate & $1,254(992-1,517)$ & $3,651(4,415-2,887)$ \\
\hline Fr. 4 MSW & $148(160-136)$ & $349(378-321)$ \\
\hline Rejected fraction & $192(210-173)$ & $263(288-237)$ \\
\hline
\end{tabular}




\begin{tabular}{|l|l|l|} 
Fresh compost & $120(132-108)$ & $180(199-162)$ \\
\hline Stabilized compost & $28(31-26)$ & $33(36-31)$
\end{tabular}

On the other hand, comparing lorry washing sludge with other fractions, it can be observed that the sulfur content is of the same order as the rest of the samples, except the stabilized compost, which is lower, due to the oxidation of sulfide to sulfate.

Table 4 shows the elements determined by X-Ray Fluorescence. Note the low concentration of $\mathrm{Cl}$ and $\mathrm{Na}$ in lorry washing sludge. The concentrations of toxic elements ( $\mathrm{Zn}, \mathrm{Cr}, \mathrm{Pb}$, and $\mathrm{As}$ ) are also small. There is no important seasonal change in the metal concentration of the lorry washing sludges. Therefore, the metal content in the wastewater is not the limiting factor in the precipitation of metal sulfides. The higher sulfide content in the summer sludge is due to the intense anaerobic environment, which is caused by high temperatures. On the other hand, the high percentages of $\mathrm{Ca}$ and $\mathrm{Ba}$ in the sludge samples (probably as carbonates and sulfates) are consistent with the high ash content.

\section{Table 4}

Elements (wt. \% on dry basis) by X-Ray Fluorescence (semi-quantitative analysis)

\begin{tabular}{|c|c|c|c|c|c|c|c|}
\hline & $\begin{array}{l}\text { Lorry } \\
\text { washing } \\
\text { sludge } \\
\text { (autumn) }\end{array}$ & $\begin{array}{l}\text { Lorry } \\
\text { washing } \\
\text { sludge } \\
\text { (winter) }\end{array}$ & $\begin{array}{l}\text { Lorry } \\
\text { washing } \\
\text { sludge } \\
\text { (summer) }\end{array}$ & Digestate & $\begin{array}{l}\text { Fr. } 4 \\
\text { MSW }\end{array}$ & $\begin{array}{l}\text { Rejected } \\
\text { fraction }\end{array}$ & $\begin{array}{l}\text { Fresh } \\
\text { compos }\end{array}$ \\
\hline $\mathrm{Ca}$ & 31.0 & 29.4 & 28.8 & 18.7 & 11.5 & 16.6 & 17.3 \\
\hline $\mathrm{O}$ & 25.4 & 24.7 & 25.4 & 19.7 & 16.5 & 15.2 & 16.0 \\
\hline $\mathrm{Si}$ & 7.57 & 6.54 & 6.97 & 5.01 & 5.81 & 2.89 & 3.0 \\
\hline $\mathrm{Fe}$ & 2.03 & 2.96 & 3.01 & 2.10 & 3.54 & 2.92 & 2.16 \\
\hline $\mathrm{Mg}$ & 1.51 & 1.85 & 1.17 & 1.14 & 0.92 & 0.70 & 0.77 \\
\hline $\mathrm{Al}$ & 1.43 & 1.38 & 2.20 & 1.07 & 0.66 & 1.07 & 0.99 \\
\hline K & 0.55 & 0.70 & 0.72 & 1.89 & 1.53 & 1.90 & 2.13 \\
\hline $\mathrm{Ti}$ & 0.34 & 0.34 & 0.39 & 0.41 & 0.58 & 0.22 & 0.31 \\
\hline $\mathrm{Na}$ & 0.33 & 0.30 & n.d. & 3.02 & 1.57 & 0.97 & 1.30 \\
\hline $\mathrm{S}$ & 0.30 & 0.45 & 0.68 & 0.91 & 0.51 & 0.70 & 0.90 \\
\hline
\end{tabular}




\begin{tabular}{|l|l|l|l|l|l|l|l|}
$\mathrm{Ba}$ & 0.27 & 0.18 & 0.12 & 0.05 & n.d. & n.d. & n.d. \\
\hline $\mathrm{P}$ & 0.20 & 0.30 & 0.34 & 0.55 & 0.41 & 0.46 & 0.60 \\
\hline $\mathrm{Sr}$ & 0.11 & 0.12 & 0.11 & 0.07 & 0.12 & 0.09 & 0.08 \\
\hline $\mathrm{Cl}$ & 0.10 & 0.15 & 0.49 & 3.29 & 1.81 & 1.97 & 2.47 \\
\hline $\mathrm{Zn}$ & 0.06 & 0.17 & 0.16 & 0.47 & 0.03 & 0.11 & 0.18 \\
\hline $\mathrm{Cr}$ & 0.05 & 0.05 & n.d. & 0.02 & 0.04 & 0.04 & 0.03 \\
\hline $\mathrm{Mn}$ & 0.04 & 0.05 & 0.04 & 0.04 & n.d. & 0.04 & 0.05 \\
\hline $\mathrm{Pb}$ & 0.03 & 0.03 & 0.03 & 0.04 & 0.04 & 0.03 & 0.03 \\
\hline $\mathrm{Cu}$ & 0.03 & 0.05 & 0.04 & 0.04 & 0.02 & 0.04 & 0.04 \\
\hline $\mathrm{Zr}$ & 0.02 & 0.02 & 0.02 & 0.02 & 0.006 & 0.02 & 0.02 \\
\hline $\mathrm{Rb}$ & 0.007 & 0.006 & 0.006 & 0.006 & 0.006 & 0.007 & 0.008 \\
\hline $\mathrm{As}$ & 0.002 & n.d. & 0.002 & 0.011 & 0.005 & n.d. & 0.001 \\
\hline $\mathrm{Br}$ & n.d. & n.d. & n.d. & 0.005 & n.d. & 0.01 & 0.007 \\
\hline
\end{tabular}

n.d. $<0.001 \%$

The results from the TG runs are reported in Fig. 1, part a (pyrolysis) and part $\mathrm{b}$ (combustion) where $w$ is the weight fraction at any time and $w_{150}$ refers to the weight fraction at $150{ }^{\circ} \mathrm{C}$ to remove the effect of water.

\section{Fig. 1}

TG and DTG curves (pyrolysis and combustion). a TG and DTG curves in $\mathrm{He}$ atmosphere (pyrolysis). b TG and DTG curves in $\mathrm{He}: \mathrm{O}_{2} 4: 1$ atmosphere (combustion) 


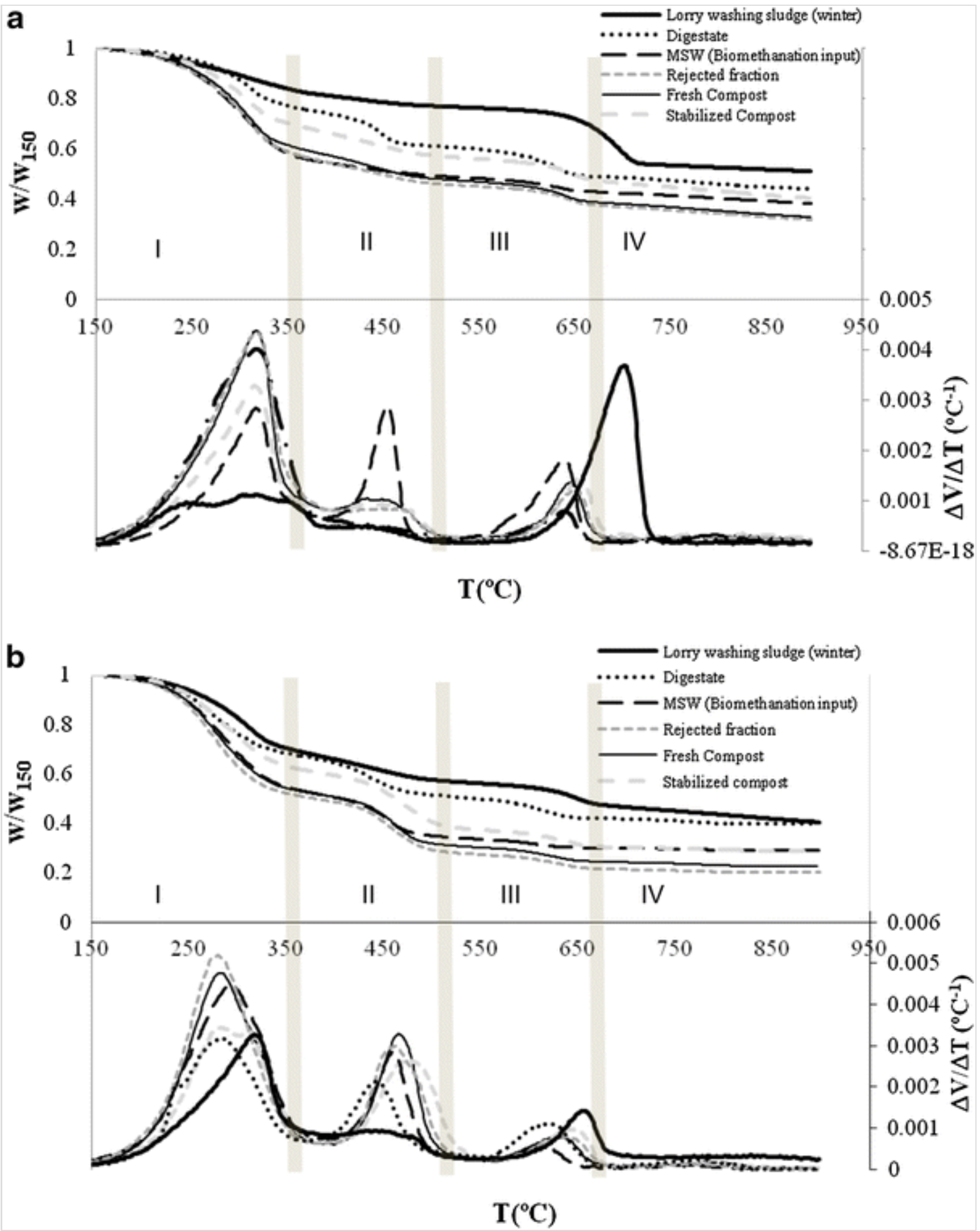

Font et al. [24] studied the kinetics of two types of sewage sludge. The most remarkable aspect of the results of this paper is the temperature range of char combustion, between 450 and $570{ }^{\circ} \mathrm{C}$.

In the case of MSW decomposition, Lai et al., [25] observed three decays for pyrolysis: the first step at $200-400{ }^{\circ} \mathrm{C}$ corresponding to cellulose and hemicellulose, the second step at $400-550{ }^{\circ} \mathrm{C}$ (small shoulder in the DTG 
curves) belonging to lignin and degradation of most of the plastics (including polystyrene, polypropylene, and polyethylene) and the third one at $700-1,000{ }^{\circ} \mathrm{C}$ corresponding to degradation of calcium carbonate and other minerals. García et al. [26] observed a weight loss in a temperature range of $710-790{ }^{\circ} \mathrm{C}$, due to the decomposition of calcium carbonate present in the MSW ash. The weight loss around $310-380{ }^{\circ} \mathrm{C}$ is due the decomposition of the cellulosic fraction, and the decomposition of other organic refuse that takes place in the range $200-500{ }^{\circ} \mathrm{C}$.

For the decomposition of compost from MSW, Pietro and Paola [27] considered two ranges of temperatures for weight loss: $210-320{ }^{\circ} \mathrm{C}$ attributed to carbohydrate decomposition and $400-520^{\circ} \mathrm{C}$ to thermal degradation of aromatic structures. Also, a slight weight loss is observed in the $695-750{ }^{\circ} \mathrm{C}$ range, attributed to the carbonate thermal decomposition. During the composting process, the carbonates weight loss increased because of their concentration.

The decay zones observed in Fig. 1 are listed as I, II, III, and IV. Taking into account, the conclusions of the papers cited previously, the following proposal is presented. Zone $\mathrm{I}$, between 150 and $350{ }^{\circ} \mathrm{C}$, mainly corresponds to the decomposition of hemicelluloses, cellulose, and low molecular weight compounds. Zone II, between 350 and $550{ }^{\circ} \mathrm{C}$ corresponds to decomposition of dead bacteria, plastics, low molecular weight compounds, and char formed previously in the combustion case. Zone III, between 550 and $650^{\circ} \mathrm{C}$, corresponds to the decomposition of high molecular weight compounds, including the oxidation of secondary products. Finally, zone IV, above $650-700{ }^{\circ} \mathrm{C}$ mainly corresponds to the $\mathrm{CaCO}_{3}$ decomposition. In the decomposition of the lorry washing sludge, the weight loss in zone IV is significant (Fig. 1 a) and is due to a high quantity of calcium carbonate in this waste. As can be observed in Table 2 (elements by X-Ray Fluorescence), the calcium content is the highest in lorry sludge samples. The DTG curve in Fig. 1 b, combustion corresponding to lorry washing sludge does not show decomposition in zone IV as great as in Fig. 1 a (pyrolysis). In addition, Fig. $1 \mathrm{~b}$ also shows higher organic degradation than in Fig. 1 a. This can be due to the fact that only $5 \mathrm{mg}$ of sample were taken and then the results can be different if a mineral or organic fraction is taken. In any case, $\mathrm{X}$-Ray Fluorescence verifies that the lorry washing sludge has a significant content of $\mathrm{CaCO}_{3}$. 
In spite of some differences between samples, the great similarity between samples can be observed.

Total halogens were measured by TOX. In the lorry washing sludge, the concentration ranges from 300 to $460 \mathrm{mg} \mathrm{Cl} / \mathrm{kg}$ d.b. The other samples studied present higher halogen concentration, ranging between 6,850 and $17,180 \mathrm{mg} \mathrm{Cl} / \mathrm{kg} \mathrm{d}$.b. and the highest concentration corresponds to the digestate sample. The lower halogen content in the lorry washing sludge is because the halides do not accumulate in the sludge, owing to their solubility.

118 semi-volatile organic compounds were identified in the studied samples. The proposed compounds have high mass spectrum coincidence with the NIST database and an effort has been made to propose names of compounds, whose boiling points are in accordance with the retention time of the chromatographic column. The limit of detection has been estimated at $0.3 \mathrm{mg} / \mathrm{kg}$ d.b., although for some compounds it can be less.

Table 5 shows a summary of the total concentration of the functional groups of organic compounds identified.

\section{Table 5}

Concentration of functional groups corresponding to semi-volatile organic compounds 


\begin{tabular}{|c|c|c|c|c|c|c|}
\hline $\begin{array}{l}\text { Alcohol } \\
\text { compounds }\end{array}$ & 2 & 11 & 18 & 13 & 57 & 26 \\
\hline Aldehydes & 3 & n.d. & 3 & 5 & n.d. & 10 \\
\hline Hydrocarbons & 62 & 253 & 2,351 & 111 & n.d. & 731 \\
\hline Aromatic & 26 & 136 & 450 & 327 & 81 & 5 \\
\hline Terpenes & 138 & 36 & 44 & 59 & 229 & 33 \\
\hline $\begin{array}{l}\text { Sulfur } \\
\text { compounds }\end{array}$ & n.d. & n.d. & 274 & 143 & n.d. & n.d. \\
\hline $\begin{array}{l}\text { Cyclic } \\
\text { compounds }\end{array}$ & n.d. & 2 & n.d. & 9 & n.d. & 6 \\
\hline $\begin{array}{l}\text { Nitrogen } \\
\text { compounds }\end{array}$ & 5 & 4 & n.d. & 85 & 32 & 19 \\
\hline $\begin{array}{l}\text { Total } \\
\text { compounds } \\
\text { identified }\end{array}$ & 1,116 & 4,414 & 29,134 & 2,202 & 10,277 & 15,940 \\
\hline
\end{tabular}

\section{$\mathrm{AQ2}$}

Carboxylic acids are the main group found in all samples; and the sample with the highest concentration was the summer sludge and the lowest concentration was the digestate. Regarding the total concentration of the semi-volatile organic compounds, the following aspects can be noted: the summer sludge is the sample with the highest concentration, and the autumn sludge presents the lowest concentration. It is, however, worth recalling that the autumn sludge was accumulated for just 1 week (the rest of the sludge studied was accumulated for 1 month). The total concentration of the digestate is also low due to its degradation during the anaerobic digestion.

Organic sulfur compounds are found in the summer sludge and the digestate.

Furthermore, in Table 5, it can be observed that the concentration of the alkanes and carboxylic acids in stabilized compost is less than in fresh compost, due to the aerobic degradation.

\section{Leachate test results}


Table 6 shows the results of ions determined by Inductively Coupled Plasma (ICP) and Hydride generation-atomic absorption spectroscopy (for $\mathrm{Hg}$ ) in the leachates. It can be observed that the concentrations of metals are small, in particular in the lorry sludge samples, and values are below the limit of Council Decision 2003/33/EC.

\section{Table 6}

Results of ions determined by ICP and atomic absorption

\begin{tabular}{|l|l|l|l|l|l|}
\hline \multicolumn{2}{|c|}{} & \multicolumn{3}{l}{ mg/kg on dry basis, mean value standard deviation (n=3) } \\
\cline { 2 - 4 } & $\begin{array}{l}\text { Sludge } \\
\text { (autumn) }\end{array}$ & $\begin{array}{l}\text { Sludge } \\
\text { (winter) }\end{array}$ & $\begin{array}{l}\text { Sludge } \\
\text { (summer) }\end{array}$ & Digestate & Fr. 4 N \\
\hline $\mathrm{Cr}$ & $0.071 \pm 0.0003$ & $0.132 \pm 0.001$ & $0.034 \pm 0.001$ & $0.50 \pm 0.06$ & $0.276 \pm$ \\
\hline $\mathrm{Ni}$ & $0.322 \pm 0.002$ & $0.292 \pm 0.003$ & $0.234 \pm 0.004$ & $0.26 \pm 0.03$ & $0.45 \pm 1$ \\
\hline $\mathrm{Cu}$ & n.d & n.d & $0.097 \pm 0.005$ & $0.01 \pm 0.01$ & $0.162 \pm$ \\
\hline $\mathrm{Zn}$ & $6.90 \pm 0.04$ & $4.43 \pm 0.03$ & $1.15 \pm 0.02$ & $4.7 \pm 0.7$ & $22.9 \pm 1$ \\
\hline $\mathrm{As}$ & $0.021 \pm 0.001$ & $0.068 \pm 0.001$ & $0.027 \pm 0.001$ & $0.15 \pm 0.02$ & $0.66 \pm 1$ \\
\hline $\mathrm{Se}$ & $0.004 \pm 0.001$ & $0.008 \pm 0.001$ & $0.060 \pm 0.001$ & $0.019 \pm 0.002$ & 0.03 \\
\hline $\mathrm{Mo}$ & $0.141 \pm 0.005$ & $0.349 \pm 0.002$ & $0.07 \pm 0.01$ & $0.01 \pm 0.01$ & $0.153 \pm$ \\
\hline $\mathrm{Cd}$ & n.d & n.d & $0.0028 \pm 0.0002$ & n.d & $0.109 \pm$ \\
\hline $\mathrm{Sb}$ & n.d & $0.091 \pm 0.004$ & n.d. & n.d & n.d \\
\hline $\mathrm{Ba}$ & $10.9 \pm 0.2$ & $32.5 \pm 0.5$ & $13.6 \pm 0.6$ & $55.8 \pm 7.2$ & $14.0 \pm 1$ \\
\hline $\mathrm{Pb}$ & $0.084 \pm 0.002$ & n.d & n.d. & $0.03 \pm 0.01$ & $0.30 \pm 1$ \\
\hline $\mathrm{Hg}$ & n.d & n.d & n.d. & n.d & n.d \\
\hline $\mathrm{C}$ & & & & \\
\hline
\end{tabular}

${ }^{\text {a }}$ Council decision 2003/33/EC

The results of total dissolved solids (TDS) and dissolved organic carbon (DOC) are shown in Table 7. The content of DOC and TDS of lorry washing sludge is less than the content of the other samples. Moreover, it is noted that the fraction of MSW exceeds the values of the Council Decision 2003/33/EC, but in this Decision it is indicated that domestic waste is accepted at the landfill without previous testing. For this reason, the lorry washing sludge could be admissible, because it comes from the 
collection of domestic waste and in addition the values obtained for DOC and TDS are lower than the values for fraction $4 \mathrm{MSW}$ (less than $4 \mathrm{~cm}$ ).

\section{Table 7}

Concentrations of dissolved organic carbon (DOC), total dissolved solids (TDS), c fluoride, sulfate, and total hydrocarbons in the leachates

\begin{tabular}{|c|c|c|c|c|c|c|}
\hline & \multicolumn{6}{|c|}{ mg/kg on dry basis, mean value (range) } \\
\hline & $\begin{array}{l}\text { DOC } \\
\text { (dissolved } \\
\text { organic } \\
\text { carbon) }\end{array}$ & $\begin{array}{l}\text { Total } \\
\text { dissolved } \\
\text { solids }\end{array}$ & Chloride & Fluoride & Sulfate & $\begin{array}{l}\text { Total } \\
\text { hydroc: }\end{array}$ \\
\hline $\begin{array}{l}\text { Lorry } \\
\text { washing } \\
\text { sludge } \\
\text { (Autumn) }\end{array}$ & $\begin{array}{l}3,110 \\
(3,180- \\
3,040)\end{array}$ & $\begin{array}{l}10,720 \\
(12,810- \\
8,640)\end{array}$ & $\begin{array}{l}310 \\
(330- \\
310)\end{array}$ & $\begin{array}{l}4.9(5.5- \\
4.4)\end{array}$ & $\begin{array}{l}910 \\
(940- \\
880)\end{array}$ & $\begin{array}{l}\text { Not } \\
\text { determi }\end{array}$ \\
\hline $\begin{array}{l}\text { Lorry } \\
\text { washing } \\
\text { sludge } \\
\text { (Winter) }\end{array}$ & $\begin{array}{l}8,350 \\
(8,530- \\
8,180)\end{array}$ & $\begin{array}{l}23,780 \\
(26,810- \\
23,780)\end{array}$ & $\begin{array}{l}680 \\
(700- \\
660)\end{array}$ & $\begin{array}{l}8.1(8.8- \\
7.3)\end{array}$ & $\begin{array}{l}800 \\
(830- \\
770)\end{array}$ & $\begin{array}{l}3,870(4 \\
3,370)\end{array}$ \\
\hline $\begin{array}{l}\text { Lorry } \\
\text { washing } \\
\text { sludge } \\
\text { (Summer) }\end{array}$ & $\begin{array}{l}13,300 \\
(13,590- \\
13,020)\end{array}$ & $\begin{array}{l}30,050 \\
(32,920- \\
27,180)\end{array}$ & $\begin{array}{l}1,730 \\
(1,780- \\
1,690)\end{array}$ & $\begin{array}{l}5.0(7.0- \\
3.0)\end{array}$ & $\begin{array}{l}340 \\
(380- \\
290)\end{array}$ & $\begin{array}{l}990(1,1 \\
870)\end{array}$ \\
\hline Digestate & $\begin{array}{l}12,080 \\
(12,480- \\
11,680)\end{array}$ & $\begin{array}{l}82,200 \\
(89,170- \\
75,230)\end{array}$ & $\begin{array}{l}4,380 \\
(4,450- \\
4,300)\end{array}$ & $\begin{array}{l}20.6 \\
(23.2- \\
18.0)\end{array}$ & $\begin{array}{l}1,120 \\
(1,160- \\
1,080)\end{array}$ & $\begin{array}{l}19,010 \\
(20,630 \\
17,400)\end{array}$ \\
\hline Fr. $4 \mathrm{MSW}$ & $\begin{array}{l}23,080 \\
(23,890- \\
22,270)\end{array}$ & $\begin{array}{l}216,780 \\
(248,950- \\
184,600)\end{array}$ & $\begin{array}{l}12,210 \\
(12,410- \\
12,000)\end{array}$ & $\begin{array}{l}69.4 \\
(73.0- \\
65.8)\end{array}$ & $\begin{array}{l}6,220 \\
(6,270- \\
6,170)\end{array}$ & $\begin{array}{l}5,910(6 \\
5,240)\end{array}$ \\
\hline $\begin{array}{l}\text { Rejected } \\
\text { fraction }\end{array}$ & $\begin{array}{l}30,740 \\
(31,390- \\
30,090)\end{array}$ & $\begin{array}{l}124,070 \\
(139,790- \\
108,350)\end{array}$ & $\begin{array}{l}6,870 \\
(7,000- \\
6,746)\end{array}$ & $\begin{array}{l}136.5 \\
(140.4- \\
132.5)\end{array}$ & $\begin{array}{l}11,820 \\
(11,870- \\
11,760)\end{array}$ & $\begin{array}{l}3,480 \\
3,110)\end{array}$ \\
\hline $\begin{array}{l}\text { Fresh } \\
\text { compost }\end{array}$ & $\begin{array}{l}38,880 \\
(39,510- \\
38,250)\end{array}$ & $\begin{array}{l}142,320 \\
(155,370- \\
129,280)\end{array}$ & $\begin{array}{l}8,830 \\
(8,950- \\
8,700)\end{array}$ & $\begin{array}{l}53.9 \\
(57.1- \\
50.6)\end{array}$ & $\begin{array}{l}10,190 \\
(10,240- \\
10,130)\end{array}$ & $\begin{array}{l}2,760(3 \\
2,420)\end{array}$ \\
\hline $\begin{array}{l}\text { Stabilized } \\
\text { compost }\end{array}$ & $\begin{array}{l}35,020 \\
(35,560- \\
34,480)\end{array}$ & $\begin{array}{l}144,120 \\
(156,130- \\
132,110)\end{array}$ & $\begin{array}{l}8,790 \\
(8,910- \\
8,670)\end{array}$ & $\begin{array}{l}218.5 \\
(222.4- \\
214.7)\end{array}$ & $\begin{array}{l}9,360 \\
(9,410- \\
9,310)\end{array}$ & $\begin{array}{l}1,370(1 \\
1,270)\end{array}$ \\
\hline $\begin{array}{l}\text { Legislation } \\
\text { limit }^{\mathrm{a}}\end{array}$ & 800 & 60,000 & 15,000 & 150 & 20,000 & - \\
\hline
\end{tabular}


Table 7 also shows the values obtained in the determination of chloride, fluoride, and sulfate leachate of the samples, determined by ion chromatography. It can also be seen that the amount of chloride, fluoride, and sulfate in washing sludge is lower than the rest of the fractions and significantly below the limit values of the Council Decision 2003/33/EC.

Regarding the results of the total hydrocarbons in the leachates (Table 7 ), it is observed that the hydrocarbon content in the lorry sludge is lower than the fraction of MSW. Therefore, the hydrocarbon content would not be a problem for the treatment of this sludge, in anaerobic treatment or composting. The corresponding fractions of compost have higher sulfate content. These results are as expected because the composting is carried out in aerobic conditions, in which sulfur present in the initial material is oxidized to sulfate. Note that the materials used in composting are the digestate and the fraction of MSW 4-8 cm. Therefore, the mixture initially has a high sulfur content which is oxidized during composting and sulfate is obtained.

Figure 2 shows the contents in sulfides and sulfates of the samples studied. Sulfates are beneficial to the soil, whose plants utilize sulfur for protein synthesis. Therefore, washing sludge as raw material for composting could also be used, since in this way, its sulfide content will be oxidized to sulfates assimilated by plants and animals.

\section{Fig. 2}

Sulfides and sulfates in samples 


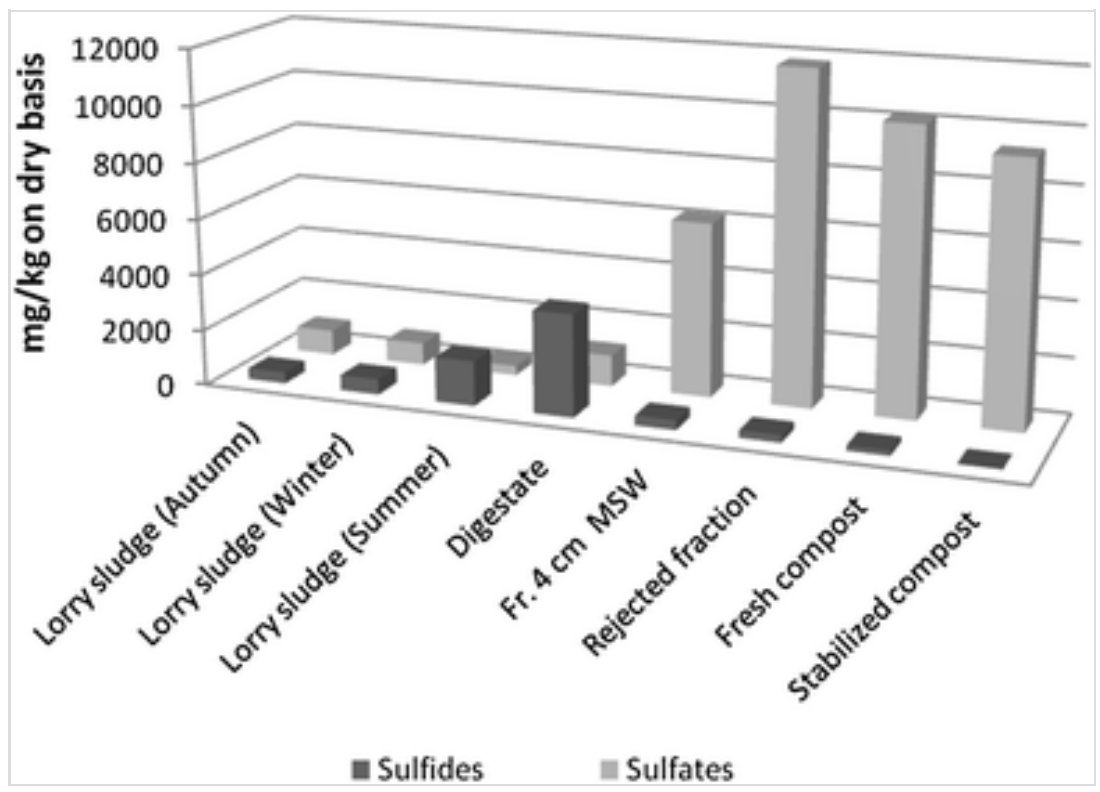

Another possible treatment of washing sludge could be energy recovery of washing sludge after drying. If the sulfur content in the sludge was high, its combustion would entail an inconvenience, because the combustion of waste that contains sulfur generates $\mathrm{SO}_{2}$. In this case, as the sludge has a low sulfur content, combustion would, therefore, not be a problem so this sludge could be energetically recovered. Table 8 shows the theoretical emissions of $\mathrm{SO}_{2}$, calculated with the results from the basic characterization of the samples, and corrected considering $6 \% \mathrm{O}_{2}$ on dry basis in the exhaust gases (according to the Spanish legislation about waste incineration, RD 653/2003).

\section{Table 8}

Theoretical emissions of $\mathrm{SO}_{2}$ from a waste co-incineration

\begin{tabular}{|l|l|}
\hline & $\begin{array}{l}\mathbf{S O}_{\mathbf{2}} \text { emissions in combustion } \\
\left(\mathbf{m g} / \mathbf{N m}^{\mathbf{3}}\right)^{\mathbf{a}}\end{array}$ \\
\hline Lorry washing sludge (Autumn) & 910 \\
\hline Lorry washing sludge (Winter) & 710 \\
\hline Lorry washing sludge (Summer) & 750 \\
\hline Digestate & 1,740 \\
\hline Fr. 4 MSW & 450 \\
\hline Rejected fraction & 1,620 \\
\hline Fresh compost & 2,060 \\
\hline Stabilized compost & 2,130 \\
\hline
\end{tabular}




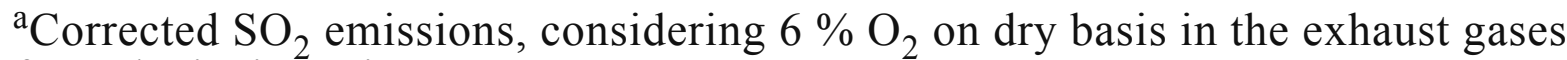
from the incineration

As can be observed in Table $8, \mathrm{SO}_{2}$ emissions from the combustion of washing sludge are practically within the legislation limit. One option could, therefore, be a co-incineration of lorry washing sludge with MSW, and another option would be exhaust gas post-treatment to reduce $\mathrm{SO}_{2}$ emissions.

\section{Conclusions}

From the chemical characterization of lorry washing sludge and comparison with other fractions of waste, a hazard cannot be attributed to lorry washing sludge. The content of metals and semi-volatile organic compounds is small and therefore does not present any hazard. Therefore, the washing sludge can be properly managed inside the MSW processing plant.

On the other hand, lorry washing sludge has high sulfur content, but the sample of digestate presents an even greater quantity of sulfur. It should be recalled that, at present, the digestate is used in the co-composting along with the fraction of MSW 4-8 cm, and the sulfide is oxidized during composting and sulfate is obtained. Therefore, the sulfur content of this sludge does not impede its composting, due to the fact that this aerobic process is currently carried out with a fraction of MSW 4-8 cm and digestate with high levels of sulfide.

In the washing sludge, the hydrocarbon content is small and less than other fractions of MSW.

\section{Acknowledgements}

The authors would like to express their gratitude to the Department of Chemical Engineering of the University of Alicante for providing support for this study.

\section{References}


1. Koster IW, Rinzema A, de Vegt AL, Lettinga G (1986) Sulfide inhibition of the methanogenic activity of granular sludge at various pH-levels. Water Res 20(12):1561-1567

2. Percheron G, Bernet N, Moletta R (1997) Start-up of anaerobic digestion of sulfate wastewater. Bioresour Technol 61(1):21-27

3. Nielsen AH, Vollertsen J, Jensen HS, Madsen HI, Hvitved-Jacobsen $\mathrm{T}$ (2008) Aerobic and anaerobic transformations of sulfide in a sewer system field study and model simulations. Water Environ Res 80(1):1625

4. Gostelow P, Parsons SA, Stuetz RM (2001) Odour measurements for sewage treatment works. Water Res 35(3):579-597

5. EPA (1974) Process design manual for sulfide control in sanitary sewerage systems. US Environmental Protection Agency (U.S. EPA) Technology Transfer, Washington

6. Meyer-Jens T, Matz G, Märkl H (1995) On-line measurement of dissolved and gaseous hydrogen sulphide in anaerobic biogas reactors. Appl Microbiol Biotechnol 43(2):341-345. doi:10.1007/bf00172836

7. Park K, Lee H, Phelan S, Liyanaarachchi S, Marleni N, Navaratna D, Jegatheesan V, Shu L Mitigation strategies of hydrogen sulphide emission in sewer networks - a review. International Biodeterioration Biodegradation (0). doi:http://dx.doi.org/10.1016/j.ibiod.2014.02.013

8. Padival NA, Kimbell WA, Redner JA (1995) Use of iron salts to control dissolved sulfide in trunk sewers. J Environ Eng 121(11):824829

9. Nielsen AH, Hvitved-Jacobsen T, Vollertsen J (2008) Effects of pH and Iron Concentrations on Sulfide Precipitation in Wastewater Collection Systems. Water Environ Res 80(4):380-384

10. van der Zee FP, Villaverde S, García PA, Fdz Polanco F (2007) Sulfide removal by moderate oxygenation of anaerobic sludge environments. Bioresour Technol 98(3):518-524 
11. Boon AG (1995) Septicity in sewers: Causes, consequences and containment. Water Science and Technology 31 (7):237-253. doi:http://dx.doi.org/10.1016/0273-1223(95)00341-J

12. Andreassi L, Flori L (1996) Mineral water and spas in Italy. Clinics in Dermatology 14 (6):627-632. doi:http://dx.doi.org/10.1016/S0738081X(96)00095-8

13. Albertini MC, Dachà $M$, Teodori L, Conti ME (2007) Drinking mineral waters: biochemical effects and health implications - The stateof-the-art. International Journal of Environment and Health 1(1):153169

14. Giampaoli S, Valeriani F, Gianfranceschi G, Vitali M, Delfini M, Festa MR, Bottari E, Romano Spica V (2013) Hydrogen sulfide in thermal spring waters and its action on bacteria of human origin. Microchemical Journal 108 (0):210-214. doi:http://dx.doi.org/10.1016/j.microc.2012.10.022

15. Gijs Kuenen J (1975) Colourless sulfur bacteria and their role in the sulfur cycle. Plant Soil 43(1-3):49-76. doi:10.1007/bf01928476

16. U.S. Environmental Protection Agengcy (1996) Method 9030B. Acid-soluble and acid-insoluble sulfides: distillation. U.S Environmental Protection Agengcy, Washington AQ4

17. U.S. Environmental Protection Agengcy (1996) Method 9034. Titrimetric procedure for acid soluble and acid insoluble sulfides. U.S Environmental Protection Agengcy, Washington

18. U.S. Environmental Protection Agengcy (1996) Method 3545. Pressurized Fluid Extraction (PFE). U.S Environmental Protection Agengcy, Washington

19. U.S. Environmental Protection Agengcy (1996) Method 8270C. Semivolatile Organic Compounds by Gas Chromatography/Mass Spectrometry (GC/MS). U.S Environmental Protection Agengcy, Washington 
20. DIN 38414-S4, Deutsche Norm (1985) Teil 4 Okt. 464-475

21. Jameel P (1989) The use of ferrous chloride to control dissolved sulfides in interceptor sewers. J Water Pollut Control Fed 61(2):230236

22. Firer D, Friedler E, Lahav O (2008) Control of sulfide in sewer systems by dosage of iron salts: comparison between theoretical and experimental results, and practical implications. Sci Total Environ 392(1):145-156. doi: http://dx.doi.org/10.1016/j.scitotenv.2007.11.008

23. Lewis AE (2010) Review of metal sulphide precipitation. Hydrometallurgy 104(2):222-234. doi:

http://dx.doi.org/10.1016/j.hydromet.2010.06.010

24. Font R, Fullana A, Conesa J (2005) Kinetic models for the pyrolysis and combustion of two types of sewage sludge. J Anal Appl Pyrolysis 74(1-2):429-438. doi:

http://dx.doi.org/10.1016/j.jaap.2004.10.009

25. Lai Z, Ma X, Tang Y, Lin H (2012) Thermogravimetric analysis of the thermal decomposition of $\mathrm{MSW}$ in $\mathrm{N} 2, \mathrm{CO} 2$ and $\mathrm{CO} 2 / \mathrm{N} 2$ atmospheres. Fuel Process Technol 102(0):18-23. doi: http://dx.doi.org/10.1016/j.fuproc.2012.04.019

26. García AN, Marcilla A, Font R (1995) Thermogravimetric kinetic study of the pyrolysis of municipal solid waste. Thermochim Acta 254(0):277-304. doi: http://dx.doi.org/10.1016/0040-6031(94)02002-6

27. Pietro M, Paola C (2004) Thermal analysis for the evaluation of the organic matter evolution during municipal solid waste aerobic composting process. Thermochim Acta 413(1-2):209-214. doi: http://dx.doi.org/10.1016/j.tca.2003.09.026 